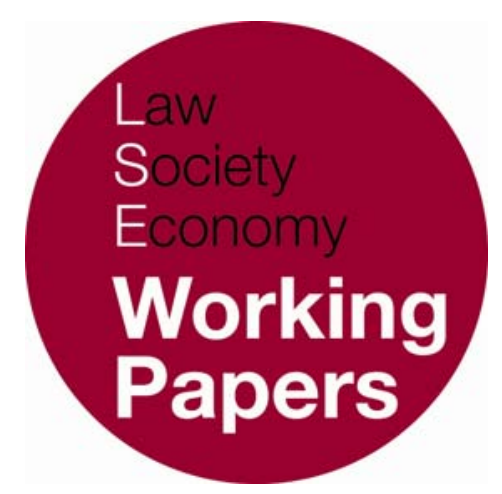

\title{
Democratic Politics in a Globalising World: Supranationalism and Legitimacy in the European Union
}

\author{
Anand Menon and Stephen Weatherill \\ LSE Law, Society and Economy Working Papers 13/2007 \\ London School of Economics and Political Science \\ Law Department
}

This paper can be downloaded without charge from LSE Law, Society and Economy Working
Papers at: www.lse.ac.uk/collections/law/wps/wps.htm and the Social Science Research
Network electronic library at: http://ssrn.comabstract=1021218.
C Anand Menon and Stephen Weatherill. Users may download and/or print one copy to
facilitate their private study or for non-commercial research. Users may not engage in further
distribution of this material or use it for any profit-making activities or any other form of
commercial gain. 


\title{
Democratic Politics in a Globalising World: Supranationalism and Legitimacy in the European Union
}

\author{
Anand Menon and Stephen Weatherill *
}

\begin{abstract}
This paper addresses the relationship between legitimacy and international organisations via a consideration of the supranational principle that lies at the heart of the European Union. It is built on two arguments. First, that using State paradigms as the startingpoint in measuring the legitimacy of the $\mathrm{EU}$ (or of any international organisations) is falsely to assume that the EU aspires to become a State. Second, that even in so far as there may be virtue in drawing on State practice to interrogate the legitimacy of the EU system, one must do so with full recognition of the failures of states in practice to live up to the worthy ideals which represent their own claims to legitimacy. The core of our analysis holds that the nature and impact of supranationalism can only be grasped in the context of an understanding of the nature of European politics as an interlocking system of European governance. To argue that the EU should become a nation state recreated at European level is, in our view, the road to (the EU's) ruin. It would not work because of the enduring absence of adequate popular support for such a project. But nor should it work. Stripping out the supranational elements of the EU as part of a quest for accountability of the type found in States makes deeply implausible assumptions about the ability of Member states deprived of the 'Community method' to solve many of the (transnational) economic, political and social problems that confront them and their citizens, while also opening up the opportunities for 'beggar-myneighbour' economic policies of the type controlled by EC trade law. Thus, we argue for an appreciation of the functions of both national and European institutions in meeting the challenge of securing legitimacy, an approach which connects to the normative reading of supranationalism that treats it as directed at 'taming', but neither eliminating, nor replacing, the Member states.
\end{abstract}

\section{INTRODUCTION}

\footnotetext{
* Anand Menon is Director of the European Research Institute, University of Birmingham. Stephen Weatherill is Jacques Delors Professor of EC Law and a Fellow of Somerville College in the University of Oxford. The authors are grateful to the British Academy for the support provided by a Small Research Grant.
} 
International organizations represent the most obvious attempt on the part of states to confront the challenges of an increasingly globalized world. Yet the proliferation of such institutions has raised profound, and often justified, concerns regarding their impact on politics, and, more specifically, on democratic politics. Whilst publics have voiced their concerns via demonstrations such as those that famously accompanied the WTO ministerial meetings in Seattle and elsewhere, eminent democratic theorists have questioned whether democracy is, in fact, conceivable 'beyond borders.'

The debate has been fiercest around the world's most developed such institution, the European Union. A series of high profile public rejections of amendments to the Union's founding treaties - from the Danish rejection of the 1993 Maastricht Treaty to French and Dutch refusals in 2005 to ratify the new constitutional treaty - have thrown popular concerns about, and dissatisfaction with, the Union into sharp relief. Meanwhile, academic debate on the so-called 'democratic deficit' has grown fiercer, broader and more disparate over recent years.

This paper addresses the relationship between legitimacy and international organisations via a consideration of the supranational principle that lies at the heart of the European Union. Much of the literature on the 'democratic deficit' argues that the formal independence and lack of accountability of the European Commission and European Court of Justice contribute significantly to the democratic failings of the EU. Cures are broadly grouped around the prescription that the supranational features of the EU, in particular in the shape of the Commission, should be subject to more aggressive forms of accountability of a type inspired by the models espoused by nation states.

In what follows, we doubt the diagnosis and consequently reject the cure. We claim that many observers exaggerate the problems by overlooking the distinctive function of the EU in reshaping Europe's political, economic and legal landscape in a manner that accepts, absorbs and seeks to remedy the failings of states. We claim that proposed cures would in fact cause real harm to the EU's ability to perform this function effectively. We do not seek to deny that European integration in general, and the role within it of the supranational institutions in particular, raise valid concerns about democratic legitimacy. However, we present an account which reveals a constructive, even symbiotic, relationship between the EU and its Member states, one in which the supranational institutions play a crucial, if often neglected, role in enhancing the legitimacy of the European governance system as a whole.

This article is built around two arguments. First, that using State paradigms as the starting-point in measuring the legitimacy of the EU (or of any international organisations) is falsely to assume that the EU aspires to become a State. Second, that even in so far as there may be virtue in drawing on State practice to interrogate the legitimacy of the EU system, one must do so with full recognition of the failures of states in practice to live up to the worthy ideals which represent their own claims to legitimacy. 
Accordingly we argue that the effectiveness of the EC system depends on the existence of the Court and the Commission as vigorous autonomous institutions. Acting effectively is itself a source of legitimacy, and so tying them into traditional notions of democratic accountability practised within a State is to measure them according to the wrong standards, while also, by undermining their autonomy and power, to damage their legitimacy judged according to the right standards. Moreover, we hold that supranationalism itself can be seen to contain a legitimating factor rooted not merely in the problem-solving capacity of the Union, but which also possesses a political dimension. Supranationalism, we argue, provides a cure for the democratic failings of Member states by embedding within national political and administrative systems legally enforceable obligations to respect the interests of actors whose voice is excluded or muffled (de jure or de facto) within purely national political processes.

Once these arguments are combined, the core of our analysis holds that the nature and impact of supranationalism can only be grasped in the context of an understanding of the nature of European politics as an interlocking system of European governance. To argue that the EU should become a nation state recreated at European level is, in my our view, the road to (the EU's) ruin. It would not work because of the enduring absence of adequate popular support for such a project. But nor should it work. Stripping out the supranational elements of the EU as part of a quest for accountability of the type found in States makes deeply implausible assumptions about the ability of Member states deprived of the 'Community method' to solve many of the (transnational) economic, political and social problems that confront them and their citizens, while also opening up the opportunities for 'beggar-my-neighbour' economic policies of the type controlled by EC trade law. Thus, we argue for an appreciation of the functions of both national and European institutions in meeting the challenge of securing legitimacy, an approach which connects to the normative reading of supranationalism that treats it as directed at 'taming', but neither eliminating, nor replacing, the Member states.

\section{THE 'DEMOCRATIC’ CRITIQUE OF SUPRANATIONALISM}

The issue of legitimacy is increasingly central to contemporary debates about international politics in general and the role of international institutions in particular. ${ }^{1}$ A central theme of much scholarship has been the concern that

${ }^{1}$ R. A. Dahl, ‘A Democratic Dilemma: System Effectiveness Versus Citizen Participation' (1994) 109(1) Political Science Quarterly, 23; R.A. Dahl, 'Can international organizations be democratic? A skeptic's view' in Democracy's Edges, I. Shapiro and C. Hacker-Cordón (eds) (Cambridge: CUP, 1999); R. W. Grant, and R. O. Keohane "Accountability and Abuses of Power in World Politics" (2005) 99(1) American Political Science Review, 29; A. Kuper, Democracy Beyond Borders: Justice and Representation in Global Institutions (Oxford: OUP, 2006); and I. Shapiro and C. Hacker-Cordón (eds) Democracy's Edges (Cambridge: Cambridge University Press, 1999). 
internationalisation 'almost invariably means a loss of democracy'. ${ }^{2}$ A key proponent of such ideas has been Robert Dahl, whose scepticism about the legitimacy of delegation in national contexts ${ }^{3}$ translated into a belief in the inherent lack of democracy of international organisations. ${ }^{4}$

The European Union has been the target of much of the most impassioned debate about the legitimacy of international institutions not least because, as Eric Stein ${ }^{5}$ has argued, there exists a correlation between the level of integration achieved and the extent of concerns regarding legitimacy. Nor should it come as a surprise that the supranational institutions are particular targets for criticism, given their unique nature as institutions formally independent of the Member states, as well as both their centrality to much of what the Union does, and their lack of any but (in the case of the Commission) the weakest form of democratic accountability.

The widening academic and political debate about democracy in the European Union is characterised by a pervasive assumption that the fundamental problem relates to a lack of democratic control over the supranational institutions. Thus, one definition of the so-called democratic deficit asserts that the democratic problems of the Union are a function of the 'shift in decision-making powers from the national to the EU level, without accompanying strengthening of parliamentary control of executive bodies'. 6

In response, some have suggested that these powers be curtailed, perhaps by denying the Commission any role in the legislative process by stripping it of its virtual monopoly over the right to propose legislation. ${ }^{7}$ Others still argue that the way to resolve the democratic problems of the Union are to provide the Commission with democratic accountability within the Union's architecture, most prominently by tying choices about its composition more closely to the Parliament. ${ }^{8}$ Even those who downplay the significance of the democratic problems within the Union are wont to express concerns with the unaccountable nature of the supranational institutions. Thus Crombez argues that the limited

\footnotetext{
2 Dahrendorf 'The Third Way and Liberty: An Authoritarian Streak in Europe's new Center' (1999) Foreign Affairs, Sept/Oct, 13.

${ }^{3}$ R. A. Dahl, Democracy and Its Critics (New Haven, Yale University Press, 1989) esp. ch. 4.

${ }^{4}$ Dahl, 'Can international organizations be democratic? A skeptic's view', n 1 above.

${ }^{5}$ E. Stein, 'International Integration and Democracy: No Love at First Sight' (2001) 95(3) The American Journal of International Law 489, 489.

${ }^{6}$ C. Archer, The European Union: Structure and Process (New York: Continuum International Publishing, 2000), 58. Such arguments are sometimes mirrored in political rhetoric (and therefore doubtless in popular consciousness too). French President General Charles de Gaulle described the European Commission in typically withering terms as a 'mostly foreign technocracy, intended to encroach upon French democracy' (cited in P. Magnette, What is the European Union? Nature and Prospects (Basingstoke: Palgrave, 2005) 171); in 2006 Wolfgang Schüssel, Chancellor of Austria, was reported to have urged the European Court to 'pay more heed to public opinion and to refrain from handing down heavy-handed judgments' (Financial Times, April 19 2006)..

7 R. Vaubel, The Centralisation of Western Europe: The Common Market, Political Integration and Democracy (London: Institute of Economic Affairs, 1995).

8 W. Van Gerven, The European Union: A Polity of States and Peoples (Oxford: Hart Publishing, 2005); B. Donnelly and M. Wagner 'Voting for Europe: Citizens, Elections and Referendums' (Federal Trust, Policy Brief Number 27, 2006).
} 
democratic failings of the Union could best be alleviated via the election of the Commission either by the European Parliament or by direct election. ${ }^{9}$

Much reasoning along these lines draws implicitly or explicitly - upon comparisons with nation states. As a consequence, their prescriptive suggestions are based on the need for the Union to mimic structures and processes that characterise national democratic systems. In a recent article on the democratic deficit, Andreas Follesdal and Simon Hix are generally careful not to compare the Union directly with nation states. ${ }^{10}$ Yet the implicit comparator is there, revealed when they argue that in 'a "normal" democracy, rival groups of elites (parties) would have incentives to develop and promote competing policy positions, a majority would form in favour of a particular policy package, and a mandate for action would be established'. Without such democratic contestation, they argue the EU will remain incapable of addressing issues of core public concern such as economic reform.

In order that EU politics be made to resemble national politics, scholars have proposed institutional reforms based on structures in place within nation states including, notably, the election of the Commission president, either directly ${ }^{11}$ or indirectly, via an 'electoral college'. ${ }^{12}$ For some, for whom the differences between the EU and Member states are all too obvious, reforms such as the election of the Commission President will serve to eliminate such differences, notably by fostering the development of a genuine European demos. ${ }^{13}$

We recognise that the more the EU acts like a State, the more tempting it becomes to expect its institutions to be accountable according to the model found in States. And we do not deny the salience of these bubbling anxieties. However, our argument is, first, that there are some things that the EU does which are simply not things that States do, such as eliminating barriers to transfrontier trade, and that different thinking about legitimacy is required in such supranationallydriven contexts: and, second, that some things that the EU does are things that (many) States do too but without expecting exposure to the full solemnity and volatility of the democratic process (such as aspects of monetary policy, competition policy, authorisation of risky products, and policy-implementation more generally), and so the need for 'democratisation' at EU level is far from clear. This then leaves a third category which we concede is more problematic: where the EU may find itself making politically sensitive choices of a type that seem to demand electorally-driven legitimation. We examine these distinct challenges

9 C. Crombez, 'The Democratic Deficit in the EuropeanUnion: Much Ado about Nothing?' (2003) 4(1) European Union Politics, 101.

${ }^{10}$ A. Follesdal and S. Hix 'Why There is a Democratic Deficit in the EU: A Response to Majone and Moravcsik' (2005) No C-05-02 European Governance Papers.

11 V. Bogdanor, 'The future of the European Community: two models of democracy' (1986) 21(2) Government and Opposition,161; F. Decker, 'Governance beyond the nation-state. Reflections on the democratic deficit of the European Union' (2002) 9(2) Journal of European Public Policy, 256.

12 S. Hix, 'Elections, parties and institutional design. A comparative perspective on European Union democracy' (1998) 2(3) West European Politics 19; S. Hix, Linking National Politics to Europe (London: Foreign Policy Centre, 2002).

13 Decker, n 11 above. 
below under an assumption that an adequately sophisticated depiction of the EU's supposed legitimacy deficiencies must take account of the inappropriateness of assuming the EU (or any international organisation) can or should be legitimated only in the way that a State can or should be.

\section{SUPRANATIONALISM AND LEGITIMACY IN THE EUROPEAN UNION}

\section{THE LEGITIMACY OF EFFICIENCY}

Fritz Scharpf has drawn a distinction between 'input' and 'output' legitimacy. ${ }^{14}$ Democratic self-determination, he insists, requires that choices made by the given political system be driven by the authentic preferences of citizens. This suggests a chain of accountability linking those governing to those governed. It is input legitimation. But 'democracy', most commonly understood in terms of this form of legitimacy, is only part of the story of political legitimacy, which also demands that those exercising political power are able to achieve a high degree of effectiveness in meeting the expectations of the governed citizens.

The democratic process is, for Scharpf, an 'empty ritual' without such delivery - output legitimacy. ${ }^{15}$ Scharpf argues vigorously and persuasively that, although the Union is regularly and (to some extent) justifiably criticised for deficiencies in input legitimacy, too little attention is paid to the inadequacies of states when judged from the standpoint of output legitimacy. The problem confronting the state has been felicitously portrayed as lying in its 'changing basis of legitimacy...from pure domination to performance of functional duties' which it may be less able to discharge effectively than other types of organisations. ${ }^{16}$ Neglect of this functional decline tends to breed an inflated assumption of the claim of states to legitimacy. Scharpf's key point is that, in at least some policy areas, it may be possible to conceive of the EU as capable of legitimation by reference to its output, even if input legitimation is lacking. In a similar vein, Giandemenico Majone argues that the Union represents and should represent a 'regulatory state'. Consequently, it is wholly appropriate that it relies largely on output legitimation. The unelected nature of the Commission and Court serve to

${ }^{14}$ F. W. Scharpf, 'Economic Integration, Democracy and the Welfare state' (1997) 4(1) Journal of European Public Policy, 18; F. W. Scharpf, Governing in Europe: Effective and Democratic? (Oxford: Oxford University Press, 1999).

15 Grant and Keohane use the notions of participation and delegation models to make a very similar distinction (R. W. Grant and R. O. Keohane, 'Accountability and Abuses of Power in World Politics' (2005) 99(1) American Political Science Review 29).

16 S. Bartolini, 'Old and New Peripheries in the Processes of European Territorial Integration' in Restructuring Territoriality, C. K. Ansell and G. di Palma (eds.) (Cambridge: Cambridge University Press, 2004) 26. 
ensure the Pareto optimality of its regulatory decisions, which would be compromised by resort to processes of input legitimation. ${ }^{17}$

Such insights carry great weight in guiding our understanding of the problems associated with the growth of regulatory activity 'above' the state. They are particularly valuable in emphasising the value that is properly attached to output legitimacy. This is especially important in the light of the effect that EU membership exerts in confining the policy options available to Member states, while not recreating equal opportunities for rule-making at transnational level. Under such arrangements, orthodox assumptions about securing input legitimacy for decisions by public bodies are undermined. A response based on reversion to unilateral, bilateral or ad hoc multilateral state action will be confronted by limitations in achieving effective problem solving. A response based on re-creating state structures at transnational level, in order to re-locate sites of input legitimacy, raises all manner of awkward problems associated with the disinclination of citizens simply to shift their sense of allegiance (see below).

Neither route needs to be followed. It is quite proper to identify a road to legitimacy paved by the ability of the Union to deliver responses to problems that would be insoluble or even simply less effectively solved by individual states. Institutions are, after all, created by states to enable them to deal with issues they could not address alone. In setting up delegated agents within the EC, Member states self-consciously took the decision to create institutions constitutionally separate from national legitimation processes, and further, by creating the Commission and ECJ as appointed institutions, failed to provide them with any direct input legitimacy of their own. Hence, whilst it is easy to understand the widespread criticism of the illegitimacy and lack of accountability of both institutions, the need for quasi-independent agencies was precisely the point of their creation. It is only through their independence that the supranational institutions are in a position to promote any Community interest, or to ensure reciprocal respect for the EU bargain.

Market-building is the most spectacular success delivered via the process of delegation to the supranational institutions. The Member states have (largely) secured the achievement of an integrated market covering the territory of the Union. This is largely attributable to the performance of both the European Court - and its allies in the national courts - in vigorously applying the relevant Treaty provisions governing, most prominently, free movement and competition policy, and the Commission - in proposing the legislative initiatives for adoption by the Council (and latterly the Parliament too) that have put in place the re-regulatory legislative framework for integration and in helping police their implementation. State regulatory autonomy is severely confined in so far as its expression may collide with inter-state trade. It may be incompatible with the Court's reading of

17 G. Majone, 'Europe's "Democratic Deficit”: The Question of Standards' (1998) 4(1) European Law Journal 5; G. Majone, 'The European Commission: The Limits of Centralization and the Perils of Parliamentarization' (2002) 15(3) Governance 375. 
the law of free movement; it may be (wholly or partially) pre-empted by the Community's legislative occupation of a particular field. ${ }^{18}$

The consequence has been the realisation of a more efficient market for Europe. The benefits of this are, of course, notoriously difficult to quantify, but a European Commission study was bullish in its claims in this regard. ${ }^{19}$ The single market offers itself as the obvious source of output legitimation that can be taken as a justification for an apparent absence of orthodox input legitimacy enjoyed by the key supranational decision-makers (beyond, of course, the simple fact of their establishment by the Member states in the first place).

Here, in the realm of technocratic market making and state taming - most conspicuously involving suppression of economic protectionism and nationalitybased discrimination - it is misleading to argue in favour of greater democratic politics since, within the EU system, these commitments have been agreed to by Member states to ensure a stable, long term and predictable future for economic actors. They are existential: to sanction protectionism and nationality-based discrimination is to tear up the Treaty. The role of the Court and the Commission in these areas therefore is perfectly amenable to output legitimation.

That is not to say that one is barred from advancing such arguments - that would evidently be absurd. But whereas it may be coherent to argue that within a State there is a case for protectionism (and presumably withdrawal from the EU), it is not coherent to transplant that debate to the EU. The EU is here performing (market-making) tasks that would not be undertaken by a State. The EU itself is premised on the legitimating factor of suppressing economic protectionism.

The enhanced effectiveness generated by the supranational regulation of transnational economic exchange therefore represents an important legitimising function of supranationalism. ${ }^{20}$ It is not, however, the sole ground on which a defence can be launched of the Commission and Court's application of the Treaty rules. There is also a political dimension to this which is tied to the failings of states.

As we have seen, much of the case for a more 'democratic' EU is based on assumptions that legitimation by states, or by structures or processes at European level that resemble those found in states, represent the most appropriate methods for ensuring the legitimacy of the Union. This, we argue, is to concede far too much to states or state-like creatures as effective and legitimate actors. Not only do the supranational institutions secure legitimacy partly through their outputs, but

\footnotetext{
$18 \mathrm{~S}$. Weatherill, 'Pre-emption, harmonisation and the distribution of competence to regulate the internal market', in J. Scott and C. Barnard (eds), The Law of the Single European Market (Oxford: Hart Publishing, 2002), chapter 2, 41-73.

19 The report claimed that the single market has had a hugely beneficial economic impact, asserting that: by 2002, EU GDP was 1.8 per cent higher than it would have been without it; that two and a half million jobs had been created that would not have been, absent that market; and that not only were European firms more competitive in the global economy, but the Union itself had become a more attractive destination for foreign direct investment (European Commission (2002) The Internal Market: Ten Years Without Frontiers, available at http://europa.eu.int/comm/internal_market/10years/docs/workingdoc/ workingdoc_en.pdf).

${ }^{20}$ E. Mestmäcker, 'On the Legitimacy of European Law' (1994) 58 RabelsZ 615.
} 
this very process of legitimation has a political dimension in that it reflects the growth of a transnational economy underpinned, not by a transnational state, but rather by a transnational 'process' that rubs away the rough, unrepresentative and illegitimate pretensions of the Member states. EU law serves as a corrective to national political processes that are unaligned with the range of interests affected by their decisions. The EU and its institutions, in other words, adjust the nondemocratic bias inherent in much national regulatory activity and many national regulatory traditions.

Maduro has observed that 'national polities have a twofold deficit: on the one hand, they do not control many decision-making processes which impact on those polities but take place outside their borders; on the other hand, national polities exclude from participation and representation many interests which are affected by its decisions'. ${ }^{21}$ In short, national-level decision making assumes what does not exist - a stable set of consumers of those decisions, whose preferences will be fully satisfied by purely national political processes and whose concerns are not shared by affected parties in other states. European law exists to correct these malfunctions. This demands an excursion into EC trade law.

The most intriguing case law arising under the Treaty provisions governing free movement of goods and services concerns situations in which a trader based in one state finds access to the market of another (the 'host state') impeded by public measures taken in that other state which, on their face, do not discriminate on the basis of origin, but rather simply differ from the rules applied in the trader's home state. It is important to appreciate that bilateral solutions are ineffective. Neither a principle of absolute host state control nor one asserting absolute home state control is capable of securing the objectives of European economic integration as set out in the Treaty. A rule of absolute host state control, depriving traders of any right to operate in new markets without adapting themselves fully to local market conditions, would subvert the very notion of competitive market restructuring and the realisation of economies of scale. A rule of absolute home state control, stripping away any role for regulation of economic activities on their territories by public bodies in so far as the relevant commercial party is based in another Member state and acting in conformity with the rules applicable there, finds no support in the Treaty. Such a model of ferocious inter-state regulatory competition is opposed by the presence of provisions such as Articles 30 and 55 EC and is more generally inconsistent with the very existence in the Treaty of a power to harmonise divergent national laws, a process which is itself required to take into account interests other than simple market-opening. ${ }^{22}$

${ }^{21}$ M. P. Maduro, 'Europe and the Constitution: what if this is as good as it gets?' in J. H. H. Weiler and M. Wind, European Constitutionalism beyond the state (Cambridge: CUP, 2003); cf C. Joerges, 'What is left of the European Economic Constitution?' (2005) 30 ELRev 461; J. Bohman, 'From Demos to Demoi: Democracy across borders' (2005) 18 Ratio Juris 293; C. Hilson, 'EU Citizenship and the Principle of Affectedness', in R. Bellamy, D. Castiglione and J. Shaw (eds), Making European Citizens: Civic Inclusion in a Transnational Context (London: Palgrave, 2006).

22 See in particular Art 95(3); in different vein, Art 95(4) et seq; and more generally the Treaty's Querschnittsklausel, Articles 6, 152(1), 153(2). 
The constitutional collision between home state and host state control needs to be managed in a more sophisticated manner than the selection of an absolute rule at either end of the spectrum. Consequently, the framework idea of a split in competence between the home state and the host state has come to play a vigorous role in the shaping of Treaty provisions governing free movement of goods and services. It has formed the basis for the European Court's bold jurisprudence which has converted the Treaty rules into a subtle, flexible and intrusive set of instruments for advancing market integration while taking account of legitimate national interests in regulatory protection.

This is famously the domain of Cassis de Dijon. ${ }^{23}$ The problem was interstate regulatory diversity; the effect was the exclusion from the German market of a product lawfully produced and marketed in France. The Court, invited to interpret the meaning of Article 28 under such circumstances, came up with an enduring formula according to which to assess whether Germany, as the host state, may prevent a product conforming to the rules of the home state, in casu France, from reaching its domestic market.

The ECJ began by insisting on the primacy of host state control in the absence of common Community rules: 'It is for the Member states to regulate all matters relating to the production and marketing of alcohol and alcoholic beverages on their own territory'. But the initial concession to the host state is deceptive. The Court proceeded to qualify this statement and to subject the permissible application of host state rules to a significant threshold requirement, adding that ' $[\mathrm{o}]$ bstacles to movement in the Community resulting from disparities between the national laws in question must be accepted in so far as those provisions may be recognised as being necessary in order to satisfy mandatory requirements'. The host state is therefore permitted to apply its rules only on condition that they carry a sufficient justification in the public interest to prevail over the interest in the integration of markets. The Court added that these 'mandatory requirements' - a most inelegant phrase, better rendered as 'compelling interests' or simply 'the public interest' 24 - included 'in particular the effectiveness of fiscal supervision, the protection of public health, the fairness of commercial transactions and the defence of the consumer'.

Moreover, in accordance with the principle that inter-state trade restrictions are treated as exceptional, the burden is on the regulating state to make the case in support of its rules. The core of the Cassis ruling therefore concludes by turning on its head the initial embrace of host state control. The Court stated that there is therefore no valid reason why, provided they have been lawfully produced and marketed in one of the Member states, alcoholic beverages should not be introduced into any other Member state; the sale of such products may not be subject to a legal prohibition on the marketing of beverages with an alcohol content lower than the limit set by the national rules'. Home state control applies

${ }^{23}$ Case 120/78 Rewe Zentrale v Bundesmonopolverwaltung fur Branntwein [1979] ECR 649.

${ }^{24}$ On the question of mis-translation, see S. Weatherill, and P. Beaumont, EU Law (Penguin Books, 3rd ed, 1999) $575, \mathrm{n} 35$. 
as a form of (judicially applied) non-absolute principle of mutual recognition. It prevails in the absence of a sufficiently compelling basis for host state control.

So dual regulation of a product or service will occur only in the limited circumstances in which the host state is able to justify its rules. The result should be the release of wider consumer choice and intensified competition as products and services, originating in other Member states but previously suppressed on export markets by local measures of market regulation, become more readily available. This shift from (national) public regulation to private autonomy in the market is central to the accomplishment of a properly-functioning common market - a core objective of the EC Treaty.

But there is a richer basis for assessing this case law than the purely economic perspectives, which would treat the output as legitimate in so far as it generates market efficiencies. A constitutional dimension invites appreciation of the interests that the Court is seeking to promote. Cassis de Dijon, along with many of its subsequent applications, illustrates the confrontation between the development of European market integration and the deadwood of centuries of regulatory tradition in all the Member states. The Court's formula stands for the need to place the regulatory autonomy of the Member states under a control exercised by EC trade law, and to insist that a justification recognised by EC law be shown for public intervention in the market. That the state's political processes have (at some point in the past) generated such a law is not of itself enough to legitimate it. Regulatory choices have to assessed in the light of their impact on wider constituencies. One might, of course, object to the values that the Court attaches to particular interests when it makes these decisions or doubt whether, say, trade integration and the interest in, for example, maintaining press diversity ${ }^{25}$ or a viable public health care system ${ }^{26}$ can truly be weighed on the same scale; additionally, one might question whether a judicial forum is the appropriate place to make such choices. ${ }^{27}$ The deeper such case law intrudes into national practices that reflect sensitive cultural, moral and social choices the more acute such anxieties become: 'Cassis de Dijon' was after all a relatively easy case! But, as a general observation, the case law offers the Court the opportunity to weed out unrepresentative and outdated manifestations of national-level decision making that are hostile to, and inappropriate in, an integrating European market of the type to which the Member states have committed themselves under the EC Treaty.

${ }^{25}$ E.g. Case C-368/95 Vereinigte Familiapress Zeitungsverlags- und vertriebs GmbH v Heinrich Bauer Verlag [1997] ECR I-3689.

26 E.g. Case C-157/99 B.S.M. Geraets-Smits v Stichting Ziekenfonds VGZ, H.T.M. Peerbooms v Stichting CZ Groep Zorgverzekeringen [2001] ECR I-5473; Case C-372/04 ex parte Watts judgment of 16 May 2006.

${ }^{27}$ E.g. Weatherill, S. 'Recent case law concerning the free movement of goods: mapping the frontiers of market deregulation' (1999) 36 CMLRev 51; M.P. Maduro, 'Striking the elusive balance between economic freedom and social rights in the EU' in P. Alston (ed), The EU and Human Rights (Oxford: OUP, 1999); R. Craufurd Smith, 'Community Intervention in the Cultural Field', in R. Craufurd Smith (ed), Culture and European Law (Oxford: OUP, 2004). 
Appreciation of the constitutional dimension is of fundamental importance to a full grasp of the nature of the process of adjudication under the law of free movement. ${ }^{28}$ Host state control, to the exclusion of the home state's preferences, would mean imports would always be required to satisfy local market rules before gaining access. This model might be taken as reflection of a pure notion of state sovereignty; or, in a more sophisticated though still inadequate perspective, as a means of connecting the accountability of the regulating authority to the parties most directly affected by trade on the territory for which the regulating authority is responsible. But such a 'pure' host state model obstructs the realisation of economies of scale, damages the pursuit of transfrontier economic restructuring and, at a deeper level, tends to oppose the very dynamic inherent in the process of not only European integration, but also globalisation.

Moreover, and as significant in terms of our focus here on legitimacy, it typically involves the exclusion of out-of-state trading interests from the rulemaking process (and the neglect of traditionally under-represented in-state interests in matters such as consumer welfare and environmental protection). That is, the connection between competence to regulate and responsibility to those affected is inadequately captured by a model which rests on assumptions of (host) state control in a European market which transcends the state. So the free movement case law 'forces' host states to justify their choices against a background which includes appreciation of their impact on affected constituencies who are not otherwise (adequately) represented in domestic political processes but who, most vividly in the case of traders with a direct commercial stake in achieving European market re-structuring, are able to rely on EC law in litigation before national courts in order to put national regulatory tradition to the test.

Political scientists have long recognised the potential benefits delegation to independent authorities can bring in terms of enhancing the legitimacy of political systems. Thus:

Delegating and insulating political power can help redress biases in national democratic representation that arise because diffuse majorities are consistently under-represented. The most common distortion is the capture of government policy by narrow but powerful interest groups opposed to the interests of majorities with diffuse, longer-term, less self-conscious concerns. ${ }^{29}$

28 M.P. Maduro, We, the Court (Hart Publishing, 1998); D. Regan, 'Regulatory Purpose and "Like Products" in Article III:4 of the GATT (with Additional Remarks on Article III:2)' in G. Bermann and P.Mavroidis (eds), Trade and Human Health and Safety (Columbia Studies in WTO Law and Policy, New York: Cambridge Univ. Press, 2006) 190-223.

29 A. Moravcsik, 'Is there a 'Democratic Deficit' in World Politics? A Framework for Analysis' (2004) 39(2) Government and Opposition 337, 346. 
A case in point is trade policy, frequently 'insulated' from democratic politics via delegation, with the result that capture by well resourced and organised protectionist interests groups becomes less likely. ${ }^{30}$

The legitimising impact of supranationalism, moreover, goes beyond the prevention of the unrepresentative poison of regulatory capture, in that the application of the rules of free movement serves to correct the malfunction of national political processes which were not attuned to the transnational realities of market integration in Europe. There is potential in the application of a comparable analysis to the Treaty rules on state Aids and public monopolies which have also frequently been relied upon by private litigants to shake up often long-standing and cosily anti-competitive domestic arrangements. ${ }^{31}$ Wider and more ambitious still, one can advocate the EC as a site for a constitution of anti-discrimination, ${ }^{32}$ capable of empowering structurally disadvantaged groups to challenge entrenched bias within national political cultures. ${ }^{33}$

In this sense EC trade law, by imposing on national political processes an obligation to respect the interests of 'foreign' actors, reflects and seeks to address the problems caused by the gap between the growth of a European market and the absence of European political institutions equipped with a general regulatory competence. ${ }^{34}$ The home state / host state model for distributing competences in the construction and management of the internal market under primary EC law is, at one level, an exercise in deregulation but, in addition, it asserts unexpectedly direct intervention in orthodox assumptions about responsibility and affected constituencies in national political decision making. This is significant in that it asserts that this apparent triumph of Market over state has a political dimension, asserting the democratic potential of supranational law for curing the deficiencies of state-level decisions taken in a transnational economy. It points to a rich notion of transnational - perhaps post-national - governance, which limits the state while not seeking to replace it with a bigger state. In other words, the democratic processes of the state are themselves lacking in an adequate European dimension where economic activity is increasingly transborder. Hence, analogies between democratic contestation within a state and its absence at EU level are flawed (see below).

\footnotetext{
30 S. Meunier, Trading Voices: The European Union in International Commercial Negotiations (Princeton: Princeton University Press, 2005) 8-9.

31 Articles 87-89 and 86 EC respectively. See e.g. on aid Case C-354/90 Féderation National de Commerce Extérieur des Produits et al $\mathrm{v}$ France [1991] ECR I-5505, on monopolies Case C-41/90 Hoefner and Elsner v Macrotron [1991] ECR I-1979 and, in between, Case C-280/00 Altmark [2003] ECR I-7747. See generally M. Smith, 'In pursuit of selective liberalization: single market competition and its limits' (2001) 8 JEPP 519; E. Szyszczak, 'Financing Services of General Economic Interest' (2004) 67 MLR 982; M. Ross, 'The Europeanization of Public Services Supervision: Harnessing Competition and Citizenship' (2004) 23 YEL 303.

32 A. Somek, 'A Constitution for Antidiscrimination: Exploring the Vanguard Moment of Community Law' (1999) 5 ELJ 243.

33 D. Chalmers, 'The Reconstitution of European Public Spheres' (2003) 9(2) ELJ 127, 184-5.

34 An absence asserted by Art 5(1) EC and forcibly confirmed by the Court in C-376/98 Germany v Parliament and Council [2000] ECR I-8419, Tobacco Advertising.
} 
A model that regards EC trade law in the light of this legitimating potential can also be fashioned in examining the pattern of harmonisation legislation. In circumstances where restrictive trading rules are shown to be justified according to the Cassis de Dijon formula, the responsibility for market-making shifts from Court to legislature. The classic response to lawful regulatory diversity is to introduce harmonised rules that accommodate the perceived need for public intervention in the market but do so in a uniform manner, at European level. 'Common rules for a common market'; the EC sets the framework for trade while also assuming the responsibility for setting a 're-regulatory' standard.

'Indirect rule' refers to the pattern according to which rule-making is located at transnational level, but the overwhelming majority of implementation and enforcement activity is allocated to and embedded within established national structures. ${ }^{35}$ It is a powerful model in that it harnesses established national legal and bureaucratic systems to the fulfilment of the Community's mission, allowing the Community to operate as a remarkably lean administration judged by the size of its own staff and direct expenditure, while also tending to sweeten the potentially alienating 'foreign' flavour of EC rules by embedding them within everyday local practice. In this sense the European Community's primary modus operandi is not at all to replace national political processes but rather to require adaptation of existing national systems, again often in the interests of un- or under- represented interests associated with the process of market integration.

There is a (developing) European market, but there is to be no replacement European state. The gap is bridged by widening the horizons of political, administrative and legal actors within the Member states. Consider a trader in home state X supplying consumers in host state Y. Interested parties in the host state no longer expect enforcement by 'their' authorities, those of state Y. Rather home state $\mathrm{X}$, implementing the Directive under the model of 'indirect rule' foreseen by Articles 10 and $249 \mathrm{EC}$, is responsible. So home state X has, via the EC's 're-regulation', become obliged to work as a law enforcement agency on behalf of consumers in host state Y. A home state acts on behalf of all Community citizens and not simply its own. ${ }^{36}$

Thus, national agencies, rooted in national systems of responsibility and accountability, become responsible for the enforcement of Community rules governing the European market. This model of home state enforcement runs directly counter to the basics of national-level representative democracy (reinforcing the latter's inaptitude as a basis for judging the EU's democratic credentials). Especially (but not only) where traders based in the home state are politically influential and where damage done by failure to police compliance with EC rules would largely be felt by citizens in host states, there are incentives for home states to adopt a lax approach to the enforcement of the 're-regulatory

35 T. Daintith, Implementing EC Law in the UK: Structures for Indirect Rule (Chichester: Wiley, 1995); J. Vervaele, Compliance and Enforcement of EC Law (Hague/London: Kluwer, 1999); E. Mastenbroek, 'EU Compliance: still a Black Hole?' (2005) 12 JEPP 1103.

36 This is made explicit e.g. in recital 22 to Directive 2000/31 on e-commerce, OJ 2000 L178/1. 
bargain'. ${ }^{37}$ EC intervention is based on the construction of a European market, but associated rule-enforcement is tied to the reality of state systems which are apt to generate decisions (about law enforcement as well as law making) that reflect powerful domestic interests, interests narrower than those affected by EU marketbuilding via secondary legislation. This calls for active supervision of the application of the EC rules. Litigation plays an important function here, and the Commission is actively seeking to build wider structures of horizontal and vertical administrative co-operation that will minimise the scope for (deliberate or unwitting ${ }^{38}$ ) defection. ${ }^{39}$ The inclusion of an insistence on improving the application of EC rules at national level in the Commission's White Paper on Governance, published in the summer of 2001, confirms that this is no mere technical matter. ${ }^{40}$ It goes to the heart of sustaining a viable system for governing the Union built on horizontal and vertical co-operation between actors at different levels rather than on any desire to make a state at European level. ${ }^{41}$

The structure of EC trade law can thus be seen to involve the injection into national political and administrative systems of obligations to respect constituencies that are affected by market integration but which lack access to the national political processes through which the European market has been built. So integration can itself be seen as a fundamentally and creatively democratic process, which helps to bridge the gap between states and European markets.

Thus, and remarkably, the national political community's place as the dominant reference point is challenged. European market building is reflected, not in European state-building, but in making national systems more European. It is a system of governance that tolerates a disconnection between the maps of political and economic unity, partly because attempts to achieve congruence are doomed to failure (the economic map can never be static), more positively because there are imaginative methods for addressing that apparent gulf which demonstrate that the quest for legitimate governance can be successfully achieved without confronting a stark choice between states in Europe or a European state. ${ }^{42}$

Ultimately, criticism of the EU as lacking the democratic credentials that are characteristic of a state is not to take as given that which is contested. It is to take as given that which is denied. The EU is not a state nor is it about to become one.

37 S. Weatherill, 'Addressing problems of Imbalanced Implementation in EC Law: Remedies in an Institutional Perspective', in C. Kilpatrick, T. Novitz and P. Skidmore (eds), The Future of Remedies on Europe (Oxford: Hart Publishing, 2000) 87-116.

38 On the breadth of reasons for non-compliance, see P. Van den Bossche, 'In search of remedies for non-compliance: the Experience of the EC' (1996) 3 MJ 371.

$39 \mathrm{~K}$. Mortelmans, 'The Common Market, the Internal Market and the single market, What's in a Market?” (1998) 35 CMLRev 101; S. Weatherill, 'New Strategies for Managing the EC's Internal Market', in M. Freeman (ed), Current Legal Problems (Oxford: Oxford University Press, Vol 53, 2000).

${ }^{40}$ COM (01) 428, 25-26. Similarly, Green Paper on EU Consumer Protection, COM (01) 531, 16-19.

41 Cf more generally F. Snyder, 'Governing Economic Globalisation: Global Legal Pluralism and European Law' (1999) 5 ELJ 334.

42 This, of course, is not simply an issue for the European Community; cf e.g. B. Rosamond, 'Discourses of globalization and the social construction of European identities' (1999) 6 JEPP 652; A-M. Slaughter, 'Global Government Networks, Global Information Agencies, and Disaggregated Democracy' (2002-03) 24 Mich J Intl L 1041; A. Von Bogdandy, 'Globalisation and Europe: How to Square Democracy, Globalisation and International law’ (2004) 15 EJIL 885. 
Yet the very combination of European institutional and constitutional architecture alongside those of the Member states itself secures a broader sense of legitimacy a legitimacy which ensures the reflection and representation of interests outside a context which is dependent on, and limited by, state systems. This perspective connects with broader notions that the EU's core function is to 'tame' states, economically but also more generally politically. It does not challenge the existence of states, but rather seeks to establish structures that restrain their corruptive capacity to inflict harm. ${ }^{43}$ So the EU both empowers states (collectively) and limits them. It is, in other words, 'a political arena designed not to replace the political arena of the nation-state but rather to supplement it in very necessary, albeit complementary, ways'. ${ }^{44}$ True, there is space for detailed argument about just how intense that supplement should be (which relates to the question as to how far EU competence can legitimately stretch under the guise of collective problem-solving in an interdependent world, addressed above with particular reference to thorny matters of redistribution and pursued further below) but the key insight of this approach is that any analysis of legitimacy must comprehend the full range of direct and indirect impacts of European norms which perform functions that are a good deal more complex - and a good deal more virtuous - than is captured by the superficial claim that they merely undermine democratic national political practices. ${ }^{45}$

This then is transnational legitimacy, rooted in a perspective that takes full account of the democratic contribution of EU law, which contributes to the input legitimacy provided at both state and European level. In fact, it is a method for accepting that input legitimation comes from both levels but that, in addition, the very process of integration, by confining state choices while not assuming their replacement at European level, changes the balance between public and private power. National constitutional systems are altered, but not via a sweeping relocation of input legitimacy to European level. Instead, the outcome of the application of the law of trade integration has itself served to eliminate undemocratic distortions lying between the state and the European Market.

It should thus be clear that to insist on comparing the EU with the democratic assumptions, institutions and style of debate found within an orthodox European state is to mis-read the very nature and purpose of the entity. The EU's game is not mimicry.

\footnotetext{
43 N. MacCormick, Questioning Sovereignty (Oxford: Oxford University Press, 1999); J. Weiler, The Constitution of Europe: Do the new clothes have an emperor? (Cambridge: Cambridge University Press, 1999).

44 D. Curtin, 'Postnational Democracy: the European Union in search of a Political Philosophy' (Inaugural Lecture, Universiteit Utrecht, 1997), 5; cf J. Shaw, 'Postnational constitutionalism in the European Union' (1999) 6 JEPP 579.

45 C. Lord, 'Assessing Democracy in a Contested Polity' (2001) 39 JCMS 641; C. Lord and D. Beetham, 'Legitimizing the EU: is there a post-Parliamentary basis for its legitimation?' (2001) 39 JCMS 443.
} 


\section{SUPRANATIONALISM - PINNING DOWN THE REAL CHALLENGE TO ITS LEGITIMACY}

Thus far we have argued that the EU's legitimacy derives from the effective discharge of its market-making tasks combined with the 'democratic' character of its trade law provisions. Its supranational institutions do not need 'input legitimacy' along state lines: more than that, the restraint of accountability would in fact damage their output legitimacy measured in capacity for effective action, and would in turn accentuate the flaws in the legitimacy to which the Member states can lay claim. We therefore sustain an argument that the EU and the Member states are mutually reinforcing - neither meets all the criteria for some perfect model of legitimacy, but each scores better when tested for (output and input) legitimacy because of the presence of the other.

But we are not for a moment suggesting that simply adopting this approach resolves the legitimacy problems confronting the Union. Scharpf himself has raised concerns based on what he sees as an anti-social democratic bias inherent in its functioning. ${ }^{46} \mathrm{~A}$ more fundamental problem concerns the scope of EU activity. Those who defend the Union against charges of illegitimacy tend to do so by means of the claim that its limited policy competence means that forms of democratic legitimation employed at the national level would be inappropriate in Brussels. For Majone, regulation is about Pareto efficiency, and can be distinguished, in both substantive and legitimacy terms, from 'redistributive' policies:

Efficiency-oriented policies attempt to increase the aggregate welfare of society, while redistributive policies are designed to improve the welfare of one particular group in society at the expense of other groups. In a nutshell: redistributive policies can be legitimated only by majoritarian means and thus cannot be delegated to institutions independent of the political process; efficiency-oriented policies, on the other hand, are basically legitimated by results, and hence may be delegated to such institutions, provided an adequate system of accountability is in place. ${ }^{47}$

Consequently, the Union must shun policies with redistributive implications because of the necessary 'strong' (input) legitimation necessary to underpin them and which the EC lacks. ${ }^{48}$ Such preferences should be expressed, if at all, only by Member states (in realms that are, in any event, often constrained by EU

\footnotetext{
${ }^{46}$ Scharpf, 'Economic Integration, Democracy and the Welfare state', n 14 above; and Scharpf, Governing in Europe: Effective and Democratic?, $\mathrm{n} 14$ above.

${ }^{47}$ Majone, 'Europe's "Democratic Deficit": The Question of Standards', n 17 above, 26.

${ }^{48}$ On connecting Majone with the work of Ipsen, see C. Joerges, 'Good Governance im Europaeischen Binnenmarkt: Über die Spannungen zwischen zwei rechtswissenschaftlichen Integrtaionskonzepten und deren Aufhebung, in A von Bogdandy, Y Meny and P Mavroides (eds), European Integration and International Co-Ordination: Liber amicorum Claus-Dieter Eblermann (The Hague: Kluwer International, 2002).
} 
membership). Legitimation, in other words, may require assessment in different ways in different policy sectors.

Andrew Moravcsik makes a similar claim in a slightly different way, arguing that current legitimation mechanisms at the EU level are appropriate because the Union simply does not handle those issues of most salience to national electorates. ${ }^{49}$ The point is that the scope of EU competence represents a crucial element of any attempt to defend it against charges of illegitimacy, as 'standards of accountability historically developed to control an omni competent state with virtually unlimited powers to tax and spend, cannot be applied without substantial modifications to a system of limited competences and resources such as the EC'. ${ }^{50}$

All of which suggests a temptingly clean-cut model according to which to define the proper limits of activity 'above' the state. The problem is, of course, that there is nothing at all clear cut about it. Even the relatively neat distinction between redistributive and efficiency-enhancing policies sketched by Majone is based on a contestable premise, as interrogated by Robert Dahl:

We can take it as axiomatic that virtually all decisions by any government, including a democratic government, are disadvantageous to some people. If they produce gains, they also result in costs. If the trade-offs in advantages and disadvantages were identical for everyone, judgements involved in making collective decisions would be roughly equivalent to those involved in making individual decisions; but the trade-offs are not the same for everyone.... In practice all substantive solutions are contested, indeed highly contested; none commands general acceptability, except perhaps in a purely formulaic way, such as Pareto optimality or the greatest good of the greatest number. ${ }^{51}$

We have argued that the EC's market-making activities are legitimated by the effectiveness of their results and by their curative effect on flaws in the representative nature of national decisions in a context of transnational trade integration. More generally, the political science literature on principal-agent relationships - which focuses largely on the place and role of independent agencies within states - identifies several factors that can be used to justify the delegation of policy functions to non-majoritarian institutions. The technicality of an issue area, the need for credibility and the need to avoid unnecessary and potentially damaging 'cycling' between competing policy alternatives figure prominently amongst these. ${ }^{52}$

The justifications for delegation are readily transplanted to the transnational context. In the case of the EU, the quest to 'tame' states, and to resolve collective

${ }^{49}$ n 29 above, 362; see also Magnette, n 6 above, chapter 2, 168.

${ }^{50}$ Majone, 'Europe's "Democratic Deficit”: The Question of Standards', n 17, 10.

${ }^{51}$ Dahl, 'Can international organizations be democratic? A skeptic's view', n 1 above, 25-6; see also n 10 above 10-12.

52 H. Kassim and A. Menon, 'The Principal-Agent Approach and the Study of the European Union' (2003) 10(1) Journal of European Public Policy 121. 
action problems between them, serves to reinforce the need for the independence of its supranational institutions. ${ }^{53}$ Such arguments take us far beyond those who propose highly restrictive rationales for delegation in the EU. At a minimum, it seems reasonable to apply as broad an interpretation of the scope of legitimate delegation as is deployed in most developed states to an institution within which additional rationales for this exist. Consequently we argue that that there are a range of administrative tasks which are no more in need of exposure to majoritarian processes at EU level than occurs at national level. The challenge here, in matters ranging from competition policy to risk management to standards setting to policy implementation generally, is to acquire legitimacy by achieving appropriate levels of transparency and participation at transnational level which meet the expectations of, without precisely replicating, best practice in good governance at national level.

Quite what governance can and should mean in the EU context is intriguing: ${ }^{54}$ nor is this an EU-specific concern, for there is a general literature which explores the conditions for the rise of a 'global administrative space'. ${ }^{55} \mathrm{We}$ do not for a moment contend this is merely a technical debate - appreciation of the vigour of the (largely negative) reaction to the Commission's rather defensive 2001 Governance White Paper $^{56}$ serves as ample rebuke to any such complacency ${ }^{57}$ and the ferocity of the disagreements over evaluation of 'comitology' is notorious ${ }^{58}$ - but we do contend that hooking the quest for improved legitimacy to electoral politics is a mistake at national level and therefore also (at least as much) at EU level.

So we reject a sweeping claim that majoritarianism should therefore form the basis of all policy decisions. But it is hard to deny Dahl's central contention that whilst, in theory, the distinction between redistributive and purely efficiencyenhancing policies may be relatively clear cut, in practice the latter are often replete with redistributive consequences. More generally, the EU's project of market-making has in part become an exercise in re-regulation, and making choices about the content of the EU regime which replaces diverse national rules is rarely apolitical (Egan, 2001; Stein 2001: $521 \mathrm{fn}$ 180). Dahl, Follesdal and Hix are certainly correct to point to the potential problems involved. 'Effectiveness' runs out of petrol as a legitimating factor in these politically contested realms.

${ }^{53}$ K. W. Abbott and D. Snidal 'Why States Act Through Formal Institutions' (1998) 42(1) The Journal of Conflict Resolution 3.

54 C. Möllers, 'European Governance: Meaning and Value of a Concept' (2006) 43 Common Market Law Review 313; C. Harlow, 'Deconstructing Government?’ (2004) 23 Yearbook of European Law 57.

${ }^{55}$ N. Krisch and B. Kingsbury, Symposium: Global Governance and Global Administrative Law in the International Legal Order, (2006) 17(1) Special Issue, European Journal of International Law; D. Esty, 'Good Governance at the Supranational Scale: Globalising Administrative Law' (2006) 115 Yale Law Journal 1490.

${ }^{56} \mathrm{n} 42$ above.

57 M. Tsatatika, 'Claims to Legitimacy: the European Commission between Continuity and Change' (2005) 43(1) Journal of Common Market Studies 193.

${ }^{58}$ C. Gerstenberg and O. Sabel, 'Directly-Deliberative Polyarchy: an Institutional Ideal for Europe?' in C. Joerges and R. Dehousse, Good Governance in Europe's Integated Market (Oxford: Oxford University Press, 2002) 289-341. 
Indeed in some areas, notably macroeconomic policy, the Union lacks the tools necessary to provide effective problem solving, while also inhibiting such problem solving at the national level, hence potentially failing any test of legitimacy even on purely output-orientated grounds. And this means that we have to consider how frequently the EU may find itself making politically sensitive choices of a type that seem to demand electorally-driven legitimation of the type found at state level. Add in examples such as immigration and asylum policy, labour market regulation and social policy and nibbles at education and cultural policy, and it becomes clear that some of what the EU currently does may not readily fit within even an enlarged conception of the scope for legitimation via non-majoritarian policy making. This is the focused, and very real, challenge to the legitimacy of the supranational enterprise.

\section{SUPRANATIONALISM AND LEGITIMACY IN THE EUROPEAN POLITICAL SYSTEM}

Efficiency gains, and the potentially democracy-enhancing role played by supranational institutions in empowering actors intimately affected by national regulatory decisions in whose formulation they play no direct role, offer strong arguments in favour of a more nuanced view of the legitimacy of the supranational institutions than a blunt demand that they behave like states. In fact, in such cases the EU is curing the failings of states. But what happens where the EU takes on tasks of a more contested nature, where the lure of national-style 'politics as usual', including direct electoral accountability, seems hard to resist as a source of legitimation?

We caution against this importation. In the first place, the proposed transplant is based on an uncritical embrace of the virtues of national political life. As noted above, many of those who criticise the European Union for its alleged absence of democratic legitimacy do so on the basis of a comparison - either implicit or explicit - with nation states. One problem with this is that several of these scholars do so based on gross caricatures of such systems, seeming 'to use an often implicit comparative referent - that of some ideal federal state in which decisions are made expeditiously, at a high level of regulation, and with full democratic participation by interest groups and social forces'. 59 Thus, Simon Hix has asserted the desirability of political contestation in the EU. ${ }^{60}$ Yet in so doing he betrays, at best, a significant degree of complacency about the virtues of national politics. In pleading for open political debate in the EU as a corrective to

59 A. M. Sbragia, 'Territory, Representation, and Policy Outcome: The United states and the European Union Compared' in C. K. Ansell and G. Di Palma (eds) Restructuring Territoriality: Europe and the United states Compared (Cambridge: Cambridge University Press, 2004) 206.

${ }^{60}$ S. Hix, 'Politics: the Right or the Wrong Sort of Medicine for the EU?' (2006) Notre Europe, Policy paper No 19. 
manipulation 'by policy entrepreneurs, such as newspaper editors, leaders of minority parties, or activists in single-issue lobby groups', ${ }^{61}$ he largely neglects the notorious inadequacy of national political debate when measured against such exacting standards (indeed, the argument of the previous section implied that the EU itself serves as an attempted corrective to the impact of such ferocious manipulation within Member states).

There are other obvious problems with such 'normative isomorphism', 62 that sees national notions of democracy applied to the EU. Not only is it virtually impossible to arrive at a consensual understanding of what 'democracy' entails in a Union containing (at least) twenty five varying conceptions of it. ${ }^{63}$ More importantly, the EU is not a nation state. Partly, as we have argued above, the difference is functional; the Union simply is not responsible for the range of policy sectors over which states have come to wield ultimate control. Partly too, structural features distinguish the Union from even federal states. ${ }^{64}$ If, as argued above, functional differences between the Union and its constituent Member states imply that the kinds of democratic legitimacy required at national level are simply not appropriate at the European level, then structural differences reinforce the point by implying that they could not be put in place anyway. One such difference is the relative institutional, constitutional and budgetary weakness of the EU. Another, deeper, feature is the absence of a European demos allowing for the effective functioning of majoritarian politics at the EU level. Ultimate political legitimacy in Europe resides in its nation states. The EU in many senses suffers from what Linz and Stepan ${ }^{65}$ refer to as a 'stateness problem', or the condition that exists 'when a significant proportion of the population does not accept the boundaries of the state (whether constituted democratically or not) as a legitimate political unit to which they owe obedience.'

Moreover, current conditions lend little succour to those who aspire to see this situation changing. One may legitimately be sceptical of the existence at European level of essential pre-conditions for democratic governance, such as a European media and genuine Europe-wide political parties, let alone of the prospects for the population of the Union to develop the kinds of 'enlightened understanding' necessary for effective democracy.66 The potential for strengthening mechanisms of input legitimacy at the EU level, therefore, is low (and, of course, lower still in wider, looser international organisations). Moreover, to attempt to import representative practices that have a modestly successful track record at state level might prove counter productive in that majoritarian principles

\footnotetext{
61 ibid, 9.

62 P. Magnette, C. Lequesne, et al.. 'Conclusion: Diffuse democracy in the European Union: the pathologies of delegation' (2003) 10(5) Journal of European Public Policy 834, 837.

63 ibid.

${ }^{64}$ Magnette $\mathrm{n} 6$ above; A. Menon, Still Less than a Federation? The EU as an International Organisation in A. Menon and M. Schain (eds) Comparative Federalism: The US and EU in Comparative Perspective (Oxford: Oxford University Press, 2006).

${ }^{65} \mathrm{~J}$. Linz and A. Stepan 'Political Identities and Electoral Consequences: Spain, the Soviet Union and Yugoslavia' (1992) 121 Daedalus 123, 123.

${ }_{66}$ Dahl, 'A Democratic Dilemma: System Effectiveness Versus Citizen Participation', n 1 above.
} 
'can work well in systems with developed national identity. But when identity is rooted in regions, majoritarianism can aggravate legitimation problems'. ${ }^{67}$ The system of EC trade law, outlined in the previous section, represents a remarkable and fragile balancing act, whereby the Union attempts to reconcile the apparent paradox of an integrated European market superimposed on diverse national cultures and preferences without aggravating legitimation problems. By contrast, increased political contestation at EU level would accentuate legitimacy problems.

The structure of legitimacy in Europe itself impacts on the functions performed by different levels of governance. Thus, to argue that that a genuine, European-level debate will engage national publics and allow the Commission to propose legislative initiatives aimed at tackling the thorny issues issue of economic reform ${ }^{68}$ is to miss the simple point that there is a limit to the weight of policy responsibility the EU can bear. As argued above, majoritarianism in systems where primary loyalties are to the parts is a potentially dangerous approach to democratic legitimation. As Joseph Weiler pointed out, citing the example of an Anschluss between Germany and Denmark:

Try and tell the Danes that they should not worry since they will have full representation in the Bundestag. Their screams of grief will be shrill not simply because they will be condemned, as Danes, to permanent minorityship (that may be true for the German Greens too) but because the way nationality, in this way of thinking, enmeshes with democracy is that even majority rule is only legitimate within a demos, when Danes rule Danes. ${ }^{69}$

In other words, absent the 'thick' collective identities associated with nation states, the kinds of trust necessary in order for majoritarian decision making to function effectively is absent; 'if there is no demos, there can be no democracy'. ${ }^{70} \mathrm{~A}$ plausible factor (among many) explaining the negative French and Dutch referendums in 2005 is a feeling of mistrust of the statist implications of the then-prevailing constitutional discourse in the EU.

We accept that the task expansion undertaken by the EU forces us to confront some awkward questions about its legitimate claim to perform increasingly sensitive functions. However, far from concluding that answers lie in promoting an intensified degree of (national-style) 'politics as usual' in the Union, which we think will only aggravate resistance to the EU's pretensions to act legitimately in such contested realms, we instead prefer to focus on the need for a

${ }^{67}$ D. McKay, Designing Europe: Comparative Lessons from the Federal Experience (Oxford: Oxford University Press, 2001) 146.

68 n 10 above.

${ }^{69}$ J.H.H. Weiler, 'The reformation of European constitutionalism' (1997) 35 Journal of Common Market Studies $97,116$.

70 ibid, 337; see also Scharpf, Governing in Europe: Effective and Democratic?, n 14 above, 8-9; for a counterargument, see I. Sánchez-Cuenca, 'The Political Basis of Support for European Integration' (2000) 1(2) European Union Politics 147. 
more informed and balanced debate about where the limits of its activity properly lie. 'More EU' will produce neither 'better EU' nor 'more legitimate EU' - it is dangerous medicine. ${ }^{71}$

\section{RE-THINKING THE RELATIONSHIP BETWEEN THE SUPRANATIONAL INSTITUTIONS AND THE MEMBER STATES}

Central to our analysis here is the notion that arguments that assume either statelevel or European legitimacy as the necessary and appropriate basis for assessing the European Union are doubly flawed - they assume one or the other instead of accepting the contributions of both. This diagnosis favours instead a model of multi-level constitutionalism, within which national and European level systems of governance interconnect. Pernice sees the European Union as a divided power system involving 'a progressive constitution of legitimate institutions and powers at the European level, which are complementary to the national constitutions and designed to meet the challenges of an evolving global society'. ${ }^{72}$ Such an approach underlines the growth of a coherent constitutional and institutional architecture for Europe, albeit that different sources must be drawn on to make real this vision - the key being not to suppose that one source has any necessary superiority (measured in any sense) over another.

Multi-level constitutionalism possesses the particular attraction that it frees us from the trap that treats the increase in private economic power in supra-state domains as a basis for shifting extra public power to that same level, which in turn draws demands for greater institutional accountability to that level, which is in turn vulnerable to the criticisms either that it impoverishes the domestic sphere or that it cannot be truly effective at EU level. It also serves as a means for releasing the study of the European Union from another unhelpful 'either/or' model, that which assumes its valid comparator is either an international organisation or a state: the international relations vs comparative public policy dichotomy. An account that emphasises the intergovernmental character of inter-state bargaining, most visible at times of Treaty revision, is not necessarily inconsistent with one that explores the interstices of policy making and policy implementation in which vertical and horizontal co-ordination between public authorities at all levels in Europe, sub-state, state and supra-state, involving a whole series of strategic but shifting alliances, escapes the direct control of national capitals. Both accounts are accurate representations of parts of the phenomenon of governance in Europe. Multi-level governance acts as a rather neat shorthand for describing the way in

${ }^{71}$ S. Bartolini 'Politics: the Right or the Wrong Sort of Medicine for the EU?' (2006), Notre Europe, Policy paper No 19.

72 I. Pernice, 'Multi-level constitutionalism and the Treaty of Amsterdam: European Constitution-Making Revisited' (1999) 36 CMLRev 703; cf M. Horeth, 'No way out for the beast? The unsolved legitimacy problem of European governance' (1999) 6 JEPP 249; N.Walker, 'The Idea of Constitutional Pluralism' (2002) 65(2) MLR 317. 
which Europe (and not only Europe) is the subject of many layers of intersecting legal and political authority, some territorially defined, others sectorally defined, not necessarily capable of subjection to a single, internally consistent rule of authority, yet working more or less successfully because of adaptation along the way and the vested interest of participants in avoiding conflict. ${ }^{73}$

Whether or not one buys into the extreme view of globalisation, according to which it is eroding the 'the authority, legitimacy, policymaking capacity and policyimplementing effectiveness of the state' ${ }^{74}$ increasing interstate trade and consequent interdependence has reduced the ability of individual governments to deliver to their electorates. Institutions such as the EU provide a means of reinforcing this ability, through both addressing the problem of negative externalities of the actions of other governments and allowing these states more effectively to shape the global economy. ${ }^{75}$ In this context, it is important to grasp that the Union not only injects an element of transnational input legitimacy into previously purely national political systems, but also serves to help address potential problems of output legitimacy at the national level. It provides a degree of welcome reinforcement to nation states struggling to meet the challenge of efficiency, 'taming' them within a sophisticated multilateral institutional framework which not only prevents them exporting ills to their neighbours, but offers them an arena both for finding common solutions to common problems and for enhancing their capacity to meet the expectations of their citizens.

Thus, a division of legitimation labour can be discerned, whereby the European level, largely reliant on output legitimacy, though also providing a forum for the articulation of out of state interests absent from national policy making, reinforces the substantive performance of Member states who, themselves, provide, via their own democratic processes and the control they exercise over the operation of the Union, the necessary element of input legitimacy. So multi-level constitutionalism has both descriptive and normative strength, in the EU context and beyond. ${ }^{76}$ The division between the 'liberal constitutional' system of the Union and the democratic systems of the Member states is, on the surface, similar that which exists between the states and the federal level in the United states. ${ }^{77}$ Its upshot is that legitimacy at each level is crucially dependent upon the effective

\footnotetext{
${ }^{73}$ Magnette $n 6$ above.

${ }^{74}$ Cerny, Philip G. 'Globalization and the Changing Logic of Collective Action'(1995) 49(4) International Organization 595, 621.

75 A. Hurrell and A. Menon, 'Institutions, International Relations and the state in Western Europe' in J. Hayward and A. Menon (eds) Governing Europe (Oxford: Oxford University Press, 2003). This in itself can be seen as a self limiting factor militating against the development of a European demos, if one accepts the argument that individuals 'are eager to make decisions at the European level when they perceive benefits at that level and when the difference between the performance of European and national institutions is unfavourable for the nation state. The demos of the supranational democracy will come into existence if and when enough people become convinced that the benefits at the supranational level are greater than the costs derived from the loss of sovereignty' (Sánchez-Cuenca, n 70 above, 168).

${ }^{76}$ M. Kumm, 'The Legitimacy of International Law: a Constitutionalist Framework of Analysis' (2004) 15(5) European Journal of International Law 907.

77 Y. Mény, 'From Popular Dissatisfaction to Populism: Democracy, Constitutionalism, and Corruption' in J. Hayward and A. Menon (eds.) Governing Europe (Oxford, Oxford University Press, 2003) 250-263.
} 
functioning of the other. Thus, the democratic legitimacy of the EU rests on the fact that national-states remain influential, democratic and technically competent. ${ }^{78}$ Seen in this light, the democratic problems that exist in the European political system stem as much from failings at the national as at the EU level. As Mény points out:

In Europe, the constitutionalist revolution has gained ground both at the national level and at the European level: the national systems have considerably reduced the input dimension of democracy, while being unable to control its output dimension, they are dependent upon regional or global market forces....Instead of compensating each other through a differentiated emphasis, as it is the case in the United states, the similarity of patterns and trends, nationally and Europe-wide, contribute to exacerbate the problems and to feed the discontent with the actual working of democracy. ${ }^{79}$

The problem, in other words, is not the lack of input democracy at EU level, but its erosion amongst the Member states themselves. ${ }^{80}$

\section{CONCLUSIONS}

It is perhaps not surprising that Europeans often express discomfort with the democratic credentials of the European Union. After all, few of them have direct experience of multilayered political systems and their often significant and complex implications for democracy. Yet supranationalism carries within itself stronger elements of legitimation than is commonly supposed. Supranational action in support of key treaty objectives such as the single market can be legitimised by reference to achievement of its economic objectives and also in terms of the role it plays in empowering actors previously excluded from purely national and often highly biased political processes.

As this paper's Introduction made explicit, we believe neglect of the legitimating virtues of supranationalism leads to exaggeration of the EU's deficiencies, but we are not so complacent as to suggest there is no 'problem of legitimacy'. Output legitimacy alone cannot provide a satisfying answer to all anxieties. The EC, and even more prominently the wider EU, has become far more than a regulatory state fixed on contained market-making objectives, in part as a result of patterns of functional spillover, in part as a result of political

\footnotetext{
78 n 29 above, 363.

$79 \mathrm{n} 77$ above, 258 .

80 Robert Dahl (in 'A Democratic Dilemma: System Effectiveness Versus Citizen Participation', n 1 above, 33) similarly argues that the improvement of democratic institutions within countries may be one way of dealing with the challenge of legitimacy and transnational governance.
} 
opportunism (in both national and supranational settings). Such incremental 'competence creep' is damaging to the EU's legitimacy. In consequence, for all the legitimating potential of supranationalism examined in this paper, it is increasingly convincing to allege that the EU simply cannot bear the weight of its own competence. Where too much is asked of the EU - and where its own institutions, most prominently the Commission, lack modesty in their portrayal of what they can deliver - the result is inflated and inevitably dashed expectations, which, moreover, encourages the tendency of national politicians to shift blame for policy failure to remote, reified 'Brussels'. ${ }^{81}$

The way to tackle those flaws, arising most conspicuously but not exclusively in areas where output legitimation is insufficient and yet input legitimation inconceivable (for want, primarily, of a European demos), does not lie in making the EU more state-like, but instead in developing a richer and much more critical culture aimed at questioning just when and why the EU should be handed new responsibilities. So the input of the European Parliament may be a necessary element in these discussions, but it is erroneous to suppose that such input is of itself sufficient to legitimate task expansion in the EU: the Parliament, though directly elected, lacks broad-based social legitimacy. In any event, the Parliament, like the other political and judicial institutions, is as much problem as solution: a more critical attitude to competence creep is more likely to come first from outwith the EU's institutionally incestuous core. 82 'Competence control' needs to be taken more seriously across the whole sweep of EU activity, in order to locate primary responsibility for politically charged choices about (in particular) redistribution where it is regarded as most legitimate - at national level. The Treaty establishing a Constitution offered some imaginative ideas, notably an attempt to devise a competence catalogue, and an explicit monitoring role for national Parliaments, whose critical voice is guaranteed by the fact that they are primary losers under the dynamic of competence creep. ${ }^{83}$ The essence of this need to question more closely why decisions should be relocated to a higher level is political but there is a constitutional dimension too, and the European Court could usefully more aggressively review legislative incursion into national autonomy ${ }^{84}$, not least under the provocative influence of national judges themselves tempted to assert such a review function. 85 Whilst the Union has contributed to the functional

${ }^{81}$ The Economist, 15 October 2005.

82 S. Weatherill, 'Competence creep and competence control' (2004) 23 Yearbook of European Law 1.

83 S. Weatherill, 'Better Competence Monitoring' (2005) 30 ELRev 23; A. Cygan, 'The role of national Parliaments in the EU's new constitutional order' in P. Tridimas and P. Nebbia (eds), EU law for the 21st Century (Oxford: Oxford University Press, 2005).

${ }^{84} \mathrm{Cf}$ in relation to Art 5(1) EC (attributed competence) Case C-376/98 note 12 above; under Art 5(2), subsidiarity, prospects are currently dim, Weatherill; n 83 above, 27-28; there may be more mileage in application of Art 5(3), proportionality control, (G. Davies, 'Subsidiarity: the wrong idea, in the wrong place, at the wrong time' (2006) 43 Common Market Law Review 63).

85 Most famously though not exclusively the Bundesverfassungsgericht: J. Schwarze (ed) The Birth of a European Constitutional Order: the Interaction of National and European Constitutional Law (Baden-Baden: Nomos, 2000); and n 76 above. 
'rescue' of the nation state, the preservation of the nation state's role as the primary site of 'politics as usual' is vital in rescuing the legitimacy of the Union.

In many federal systems, territorially distinct populations may accept the legitimacy of the central government, but only on the condition that what it does in policy terms is limited in some way or other. ${ }^{86}$ Reliable limitation is the EU's most pressing current quest. ${ }^{87}$

Clearly, the task of neatly specifying the specific kinds of issue amenable to different kinds of legitimation is in its necessary detail beyond the scope of this article. So too the intimately associated questions of institutional design, and the increasingly patchy, poorly-drafted quality of the laws approved by the Member states and the European Parliament, over which the supranational institutions are obliged to rule. Rather, what we have sought to do is expose some of the limitations of models that respond to the tensions injected by the EU's geographical and functional expansion by insisting on greater input legitimacy. Such a cure would likely amplify the problems of dissatisfaction with the legitimacy of EU-level decision-making in politically sensitive realms, while also impeding the effective performance of the core tasks currently asked of the supranational institutions. Accordingly we urge more careful analysis of the possibilities of multi-level sources of legitimacy stemming from both states and the Community or wider Union.

The 'problem with states' is not merely that they may be incapable of effective problem-solving. The rise of transnational economies does more than simply diminish state problem-solving capacity, it also tends to accentuate the extent to which state decisions may be driven by the orthodox pressures of national-level representative democracy and yet impose costs on actors who, while intimately affected by those decisions, are only inadequately represented in the state's political processes. The juxtaposition of state political decision-making and burgeoning transnational economic activity allows or even induces states to externalise costs and a method is required for reducing, if not eliminating, the ability of the state to take decisions which are neglectful of costs imposed on parties who are not able to gain (adequate) access to the (domestic) market for votes. A supranational legal order is capable of achieving this, and exploration of its legitimacy should encompass respect for this capacity Consideration of political legitimacy in an age of globalisation and increasing transnational exchange thus entails a need to think more broadly and creatively than the restrictive and restricting concept of the nation state allows. It requires appreciation of the potential of international institutions for not only contributing to efficiency gains, but also compensating for outmoded or unrepresentative political processes within

${ }^{86} \mathrm{n} 67$ above, 17; $\mathrm{cf}$ K. Nicolaidis and R. Howse, The Federal Vision: Legitimacy and Levels of Governance in the United states and the European Union (Oxford: Oxford University Press, 2001); and D. Halberstam, 'Of Power and Responsibility: the Political Morality of Federal states' (2004) 90 Virginia Law Rev 731.

87 L. Thorlakson, 'Building Firewalls or Floodagtes? Constitutional Design for the European Union' (2006) 44 JCMS 139. 
states, and all this without seeking to replicate the nature of these state structures at the international level. 